\title{
The ex vivo correlate of the antithrombotic action of Heparin
}

Citation for published version (APA):

Hemker, H. C., Beguin, S., Pieters, J., \& Lindhout, T. (1989). The ex vivo correlate of the antithrombotic action of Heparin. Annals of the New York Academy of Sciences, 556(1), 146-157.

https://doi.org/10.1111/j.1749-6632.1989.tb22498.x

Document status and date:

Published: 01/06/1989

DOI:

10.1111/j.1749-6632.1989.tb22498.x

Document Version:

Other version

\section{Please check the document version of this publication:}

- A submitted manuscript is the version of the article upon submission and before peer-review. There can be important differences between the submitted version and the official published version of record.

People interested in the research are advised to contact the author for the final version of the publication, or visit the DOI to the publisher's website.

- The final author version and the galley proof are versions of the publication after peer review.

- The final published version features the final layout of the paper including the volume, issue and page numbers.

Link to publication

\footnotetext{
General rights rights.

- You may freely distribute the URL identifying the publication in the public portal. please follow below link for the End User Agreement:

www.umlib.nl/taverne-license

Take down policy

If you believe that this document breaches copyright please contact us at:

repository@maastrichtuniversity.nl

providing details and we will investigate your claim.
}

Copyright and moral rights for the publications made accessible in the public portal are retained by the authors and/or other copyright owners and it is a condition of accessing publications that users recognise and abide by the legal requirements associated with these

- Users may download and print one copy of any publication from the public portal for the purpose of private study or research.

- You may not further distribute the material or use it for any profit-making activity or commercial gain

If the publication is distributed under the terms of Article $25 \mathrm{fa}$ of the Dutch Copyright Act, indicated by the "Taverne" license above, 


\title{
The ex Vivo Correlate of the Antithrombotic Action of Heparin
}

\author{
H. C. HEMKER, S. BÉGUIN, J. PIETERS, \\ AND T. LINDHOUT \\ Department of Biochemistry \\ University of Limburg \\ Maastricht, The Netherlands
}

The advent of low-molecular-weight heparins (LMWH) made it surprisingly clear how little we know about the connection between the antithrombotic potency of heparin and its (bio)chemical properties. Classical unfractionated heparin (UFH) has been shown to be an acceptable antithrombotic, although the bleeding risk that it may induce is not negligible. More than half a century of clinical trial and error, often of a type that would not stand up to modern ethical and scientific standards, have been necessary to find an acceptable dosage scheme. We simply cannot think of repeating the same procedure with each new type of heparin that is introduced. Therefore, we have to compare new heparins with the classical preparations on the basis of laboratory tests. Given this situation, it is slightly awkward that we do not know what the laboratory properties of heparin are that indicate its antithrombotic or hemorrhagic activities. The search for the proper laboratory correlate to in vivo antithrombotic action has occupied us for the last few years. We feel that this subject is a central one in heparin research. Only if we know what tests in the laboratory reflect the action of heparins in a patient, can we attempt to answer the three crucial questions that are posed by these drugs:

1. What tests are suitable for controlling the quality of heparin therapy in a patient?

2. How can different types of heparin be standardized, i.e., what amount of LMWH is the functional equivalent of $1 \mathrm{U}$ of standard heparin?

3. What laboratory tests indicate the antithrombotic potency of an unknown heparin?

The ultimate answer to the question of the ex vivo correlate to in vivo action cannot come from the laboratory alone, because the proof of the heparin pudding will always remain in the clinical eating. Yet on the basis of laboratory studies, we can exclude certain possibilities. If, for instance, it can be demonstrated that the anti-factor Xa action of UFH does not play a role in the thrombin generation in plasma, then it is highly unlikely that anti-factor Xa activity could relate to antithrombotic activity. Therefore, on the basis of laboratory results one can make an educated guess and put forward hypotheses on the mode of action of heparin in vivo and hence on the laboratory correlate to that.

\section{Is the Correlate To Be Found in the Coagulation System?}

One may well argue that the antithrombotic action of heparins does not necessarily have anything to do with its action on blood coagulation. In fact, many actions of heparin are known apart from its effects on the blood coagulation 
system. ${ }^{1-7}$ It has, for instance, been described that heparin fractions with a low affinity to antithrombin III (ATIII) and consequently with a limited effect on blood coagulation potentiate the effect of high-affinity fractions. ${ }^{8}$ Such findings need not automatically indicate a mode of action of heparin that bypasses the coagulation system. As soon as plasma forms part of the reaction medium, especially when it contains or has contained activated platelets, various heparin-neutralizing proteins are present. Heparins with a low affinity to ATIII may still have a high affinity to heparin-neutralizing proteins. If such heparins bind to neutralizing factors, they will automatically cause an increased availability of heparins with a high ATIII affinity.

One argument pretty well excludes the possibility that the anticoagulant properties of heparins have nothing to do with their antithrombotic action: a completely different family of anticoagulant drugs, the vitamin-K-antagonist coumarin congeners, are also good antithrombotics. These oral anticoagulants, like heparin, have several effects that are not related to blood coagulation, but these are completely different from the noncoagulation effects of heparin (for a review, see ref. 9).

The only action that, to our knowledge, coumarin congeners have in common with heparin is their anticoagulant action. Against this argument one can make the point that a third recognized antithrombotic, viz., aspirin, has no anticoagulant properties. ${ }^{10}$ This is certainly true if one investigates platelet-poor plasma. In platelet-rich plasma, however, the procoagulant action of platelets can be inhibited by aspirin. ${ }^{11}$ This leaves open the possibility that in this case also inhibition of thrombin formation is the essential mode of action of the drug, whether it be mediated by inhibition of cyclooxygenase or not.

We conclude that for the moment it is reasonable to assume that the antithrombotic action of heparin is related to its antithrombin action.

\section{Is Factor Xa Inhibition the Laboratory Correlate to Antithrombotic Action?}

When evidence was produced suggesting that LMWH might be as good an antithrombotic agent as UFH is and at the same time induce a lesser bleeding risk, it was logical to think that the yardstick for the safety of a heparin was to be found in a property that was different in both types of heparin. Such a property was found to be the relative anti-factor Xa potency. LMWHs with decreasing chain length gradually loose their antithrombin action, but to a certain extent retain their anti-factor $\mathrm{Xa}$ action. It was therefore thought that the anti-factor $\mathrm{Xa}$ action indicated the antithrombotic properties and that antithrombin activity parallels the bleeding risk. ${ }^{12-20}$

For some time it therefore has been thought that anti-factor $\mathrm{Xa}$ action was a crucial property of all heparins. In the last few years this proposition has been doubted on various grounds. ${ }^{21-27}$ It is surprising to see that in fact the ratio between the antithrombin potency of LMWH and its antifactor Xa potency does not differ significantly from that of UFH in a purified system (TABLE 1). On the other hand, the difference does appear when anti-factor Xa units are determined by the standard procedure, i.e., by measuring the decay of added factor $\mathrm{Xa}$ in plasma. The setup that uses whole plasma probably approaches the in vivo situation better than the purified system does, but still the addition of a large amount of isolated factor Xa far from mimicks physiological conditions.

We approached the question by measuring the functional factor Xa activity in clotting plasma in a situation as close as possible to the situation in vivo. We 
TABLE 1. Breakdown Constants of Various Clotting Proteases with Different Heparins in a Purified System ${ }^{a}$

\begin{tabular}{lccccc}
\hline \multicolumn{1}{c}{ Heparins } & IIa & IXa & Xa & XIa & IIa/Xa \\
\hline Standard & 38.7 & 0.180 & 4.1 & 0.021 & 9.4 \\
PK 10169 & 7.3 & 0.109 & 0.8 & 0.002 & 9.1 \\
CY 216 & 2.87 & 0.101 & 0.27 & 0.001 & 10.6 \\
CY 222 & 1.91 & 0.058 & 0.45 & 0.002 & 4.2 \\
Pentasaccharide & 0 & 0.032 & 11.4 & 0.003 & 0 \\
EMT 966 & 14.8 & 0.158 & 1.3 & 0.006 & 11.4 \\
EMT 967 & 0 & 0.020 & 0.4 & 0.001 & 0 \\
\hline
\end{tabular}

${ }^{a}$ Values are in $\min ^{-1}(\mu \mathrm{g} \text { heparin/ml })^{-1}$

developed a method that allows calculation of the activity of prothrombinase in clotting plasma. ${ }^{28}$ Prothrombinase is the complex of factor $\mathrm{Xa}$ and factor $\mathrm{Va}$ adsorbed onto procoagulant phospholipid, only in this complex factor Xa acquires kinetic properties that enable it to activate prothrombin at physiologically relevant velocities. ${ }^{29}$

It is known that factor $\mathrm{Xa}$, when functioning in prothrombinase, is protected from antithrombin III and heparin action by phospholipid and factor $\mathrm{Va}{ }^{30-38}$ The burst of prothrombinase activity in plasma is short because the available prothrombin in clotting plasma exhausts rapidly. We wanted to know whether prothrombinase in clotting plasma during the time that it actually produces thrombin is inhibited by heparin. We reasoned that at any moment the velocity of observed thrombin generation is the sum of the velocities of prothrombin conversion and of thrombin breakdown (FIG. 1). We showed that thrombin breakdown is a pseudofirst-order process with a breakdown constant that does not change during the time course of the thrombin generation curve.$^{28}$ This means that at any point of the curve we can calculate the velocity of thrombin breakdown if we know the concentration of free thrombin. The formation of the amidolytically active $\alpha_{2}$ macroglobulin-thrombin complex complicates the algorithm but does not invalidate the approach. The calculations are readily carried out by a personal computer. By applying this method it is possible to obtain the time course of prothrombinase activity from the thrombin generation curve. This curve gives more important information than the course of factor $\mathrm{Xa}$ activity, in the sense that it gives the factor $\mathrm{Xa}$ activity only insofar as it is involved in prothrombin conversion.

When we computed prothrombinase activity in the presence of various concentrations of heparin, it appeared that heparin concentrations inhibited the observed velocity of thrombin generation for up to $85 \%$, but would not inhibit prothrombinase (FIG. 2). This means that, for all practical purposes heparin does not inhibit factor $\mathrm{Xa}$ insofar as it is active in prothrombin conversion but scavenges the thrombin formed. This already clearly indicates that anti-factor Xa action cannot be the ex vivo property we are looking for, because heparin is a good antithrombotic and yet has no anti-prothrombinase activity to speak of. Clotting factors activated in situ tend to have properties that differ from isolated clotting proteases. This holds not only for factor $\mathrm{Xa}$ but also for thrombin. In general, the breakdown constants of endogenous thrombin in plasma are lower than those found with the purified protease.

To our surprise, two low-molecular-weight heparins were found to act primarily on thrombin, just like UFH. Two very low molecular weight heparins; the 
synthetic pentasaccharide that represents the high-affinity ATIII binding site of heparin and the very low molecular weight fraction of enoxaparine (fraction B), were shown to be completely devoid of anti-IIa activity. The inhibition of the generation of thrombin by these heparin fractions, therefore, is solely caused by their inhibitory action on prothrombinase (FIG. 3 and TABLE 2).

It thus appears that there are two entirely different types of heparin. Those that act virtually only on thrombin and those that act only on prothrombinase. The first we called S-type heparins after their prototype, standard heparin. They comprise both UFH and different LMWHs. The second type, the P-type heparins, of which the above-mentioned pentasaccharide is the prototype, acts on prothrombinase, but not on thrombin. Only very low molecular weight heparins belong to this group.

Inspection of prothrombinase activity curves in the presence of heparin shows that, although the peak activity is not inhibited, the velocity with which the peak is attained is lower in the presence of heparin (FIG. 2B). This must be attributed to inhibition of the generation of either factor Xa or factor Va. Direct measurement of the activity of these two factors in clotting plasma shows that both are inhibited but both in a different way. Because the main activator of factor $\mathrm{V}$ is thrombin, it stands to reason that the inhibition of factor $\mathrm{V}$ activation is a result of thrombin scavenging, whereas factor $\mathrm{Xa}$ is scavenged directly. This does not contradict our earlier conclusion that factor $\mathrm{Xa}$ in prothrombinase is not inhibited by heparin. The quantity of prothrombinase necessary to activate all the prothrombin present is exceedingly small $(<0.1 \mathrm{nM})$. Factor $\mathrm{Xa}$ is generated in large excess (peak

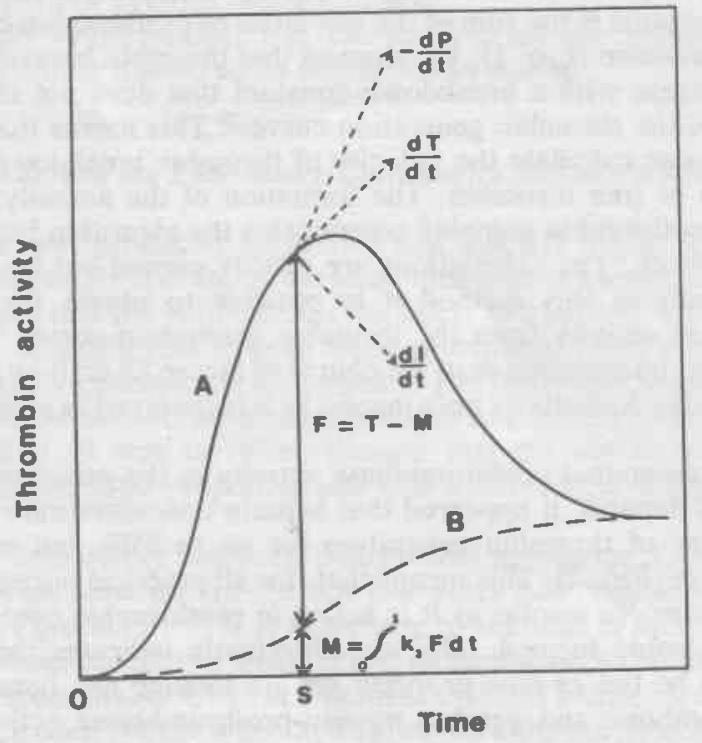

FIGURE 1. The analysis of the thrombin generation curve. Line $A$ is the experimentally observed amidolytic thrombin activity $(T)$. Line $B$ represents the activity of the $\alpha_{2}$-macroglobulin thrombin complex $(M)$. At any given moment $(S)$, the amount of free thrombin $(F)$ can be calculated $[F=T-M]$. Then the breakdown velocity of thrombin can be found $\left[\mathrm{d} I / \mathrm{d} t=\left(k_{1}+k_{2}\right) F\right]$ and the prothrombin conversion velocity obtained $[-\mathrm{d} P / \mathrm{d} t=\mathrm{d} T / \mathrm{d} t+$ $\mathrm{d} I / \mathrm{d} t]$. 


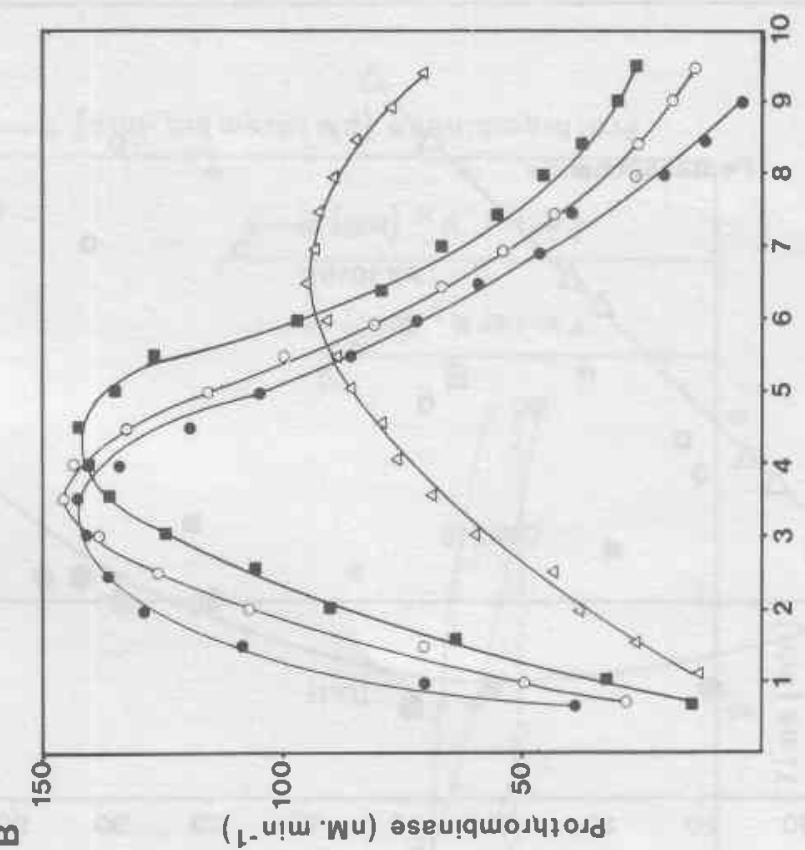

号

零 8

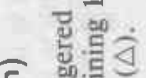

ह ह

ㅇํㄴ

E

Ex $\frac{1}{2}$

它焉

施政

䓜

ชี ษ

들 울

튼훙

ㅎํㅇ.

흠

ติ है ซै

둥ㅇ

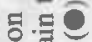

$\boldsymbol{\infty}$

( L- u!w 'wu) әseu!qwosyłord

究

는

政

도올

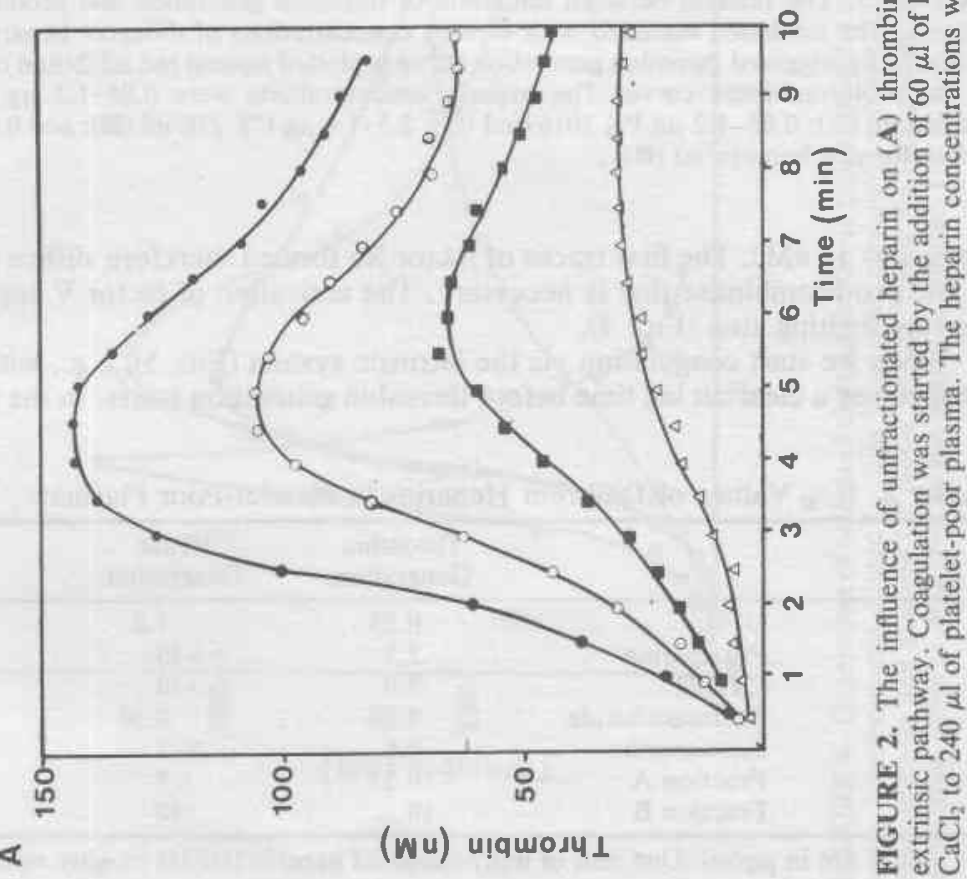




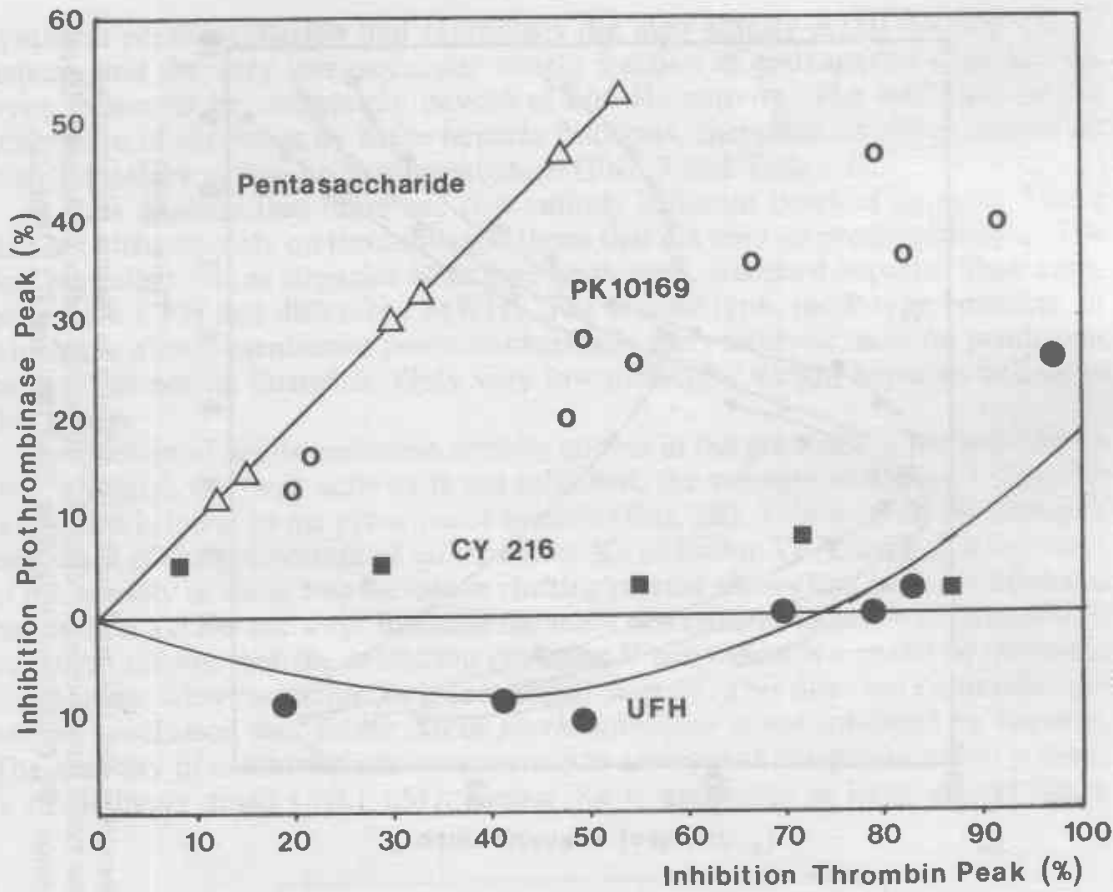

FIGURE 3. The relation between inhibition of thrombin generation and prothrombinase activity. The inhibition obtained with various concentrations of different heparins on the extrinsically triggered thrombin generation curve is plotted against the inhibition of the peak of the prothrombinase curve. The heparin concentrations were $0.05-1.2 \mu \mathrm{g}$ pentasac-

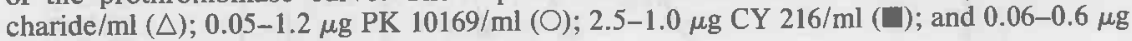
unfractionated heparin/ml (Ө).

amount $=12 \mathrm{nM}$ ). The first traces of factor Xa formed therefore suffice to obtain all the prothrombinase that is necessary. The activation of factor V seems to be the rate-limiting step (FIG. 4).

When we start coagulation via the intrinsic system (FIG. 5), e.g., with kaolin, we then see a clearcut lag time before thrombin generation starts. In the presence

TABLE 2. $\mathrm{IC}_{50}$ Values of Different Heparins in Platelet-Poor Plasma ${ }^{a}$

\begin{tabular}{lcc}
\hline & $\begin{array}{c}\text { Thrombin } \\
\text { Generation }\end{array}$ & $\begin{array}{c}\text { PTase } \\
\text { Generation }\end{array}$ \\
\hline UFH & 0.25 & 1.2 \\
Fraxiparine & 2.5 & $>>10$ \\
CY 222 & 2.0 & $>>10$ \\
Pentasaccharide & 0.10 & 0.10 \\
Enoxaparine & 0.6 & $>5$ \\
Fraction A & 0.25 & 5 \\
Fraction B & 10 & 10 \\
\hline
\end{tabular}

${ }^{a}$ Values are in $\mu \mathrm{g} / \mathrm{ml}$. One unit of unfractionated heparin (UFH) roughly equals $6 \mu \mathrm{g}$. 


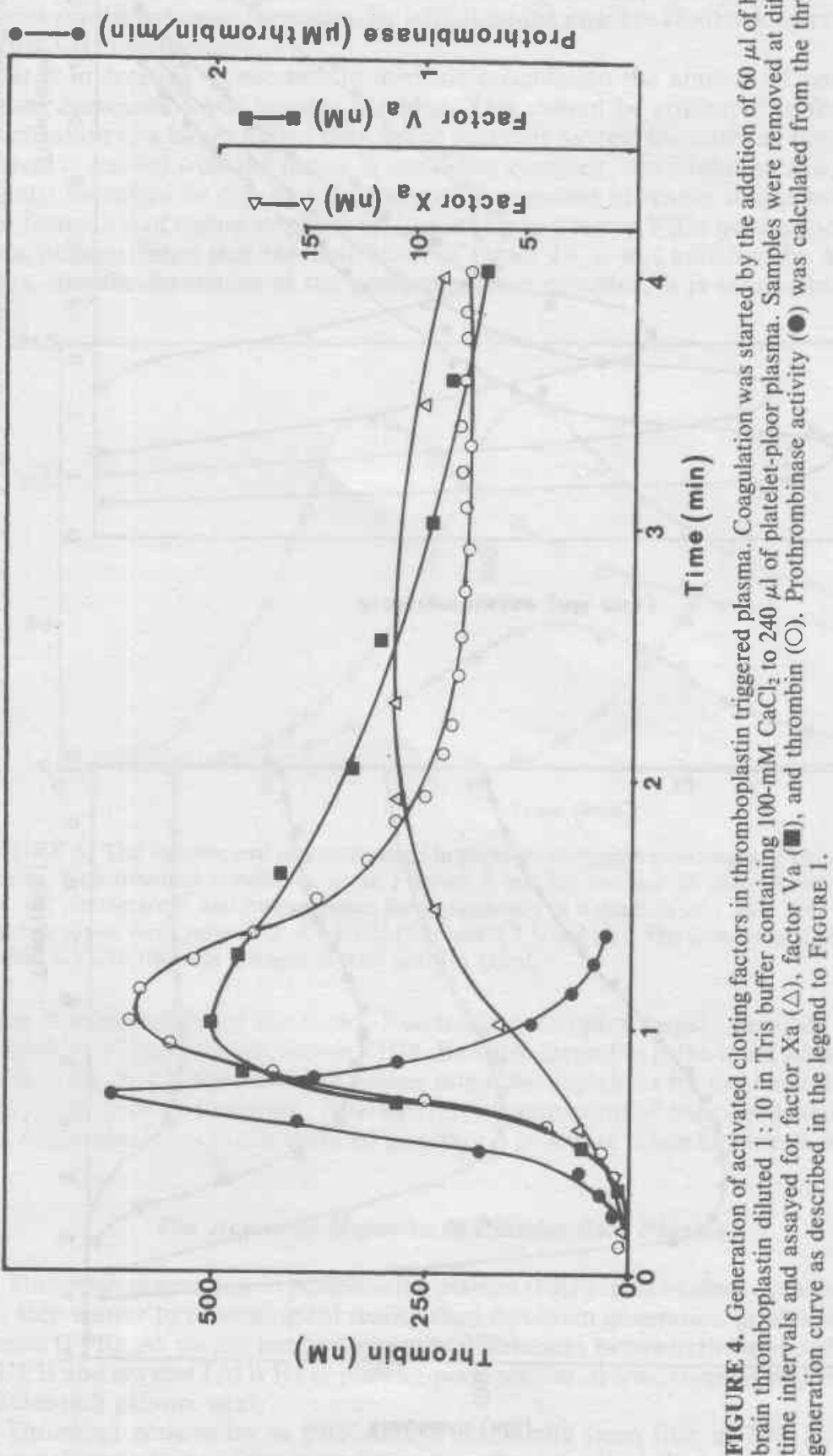




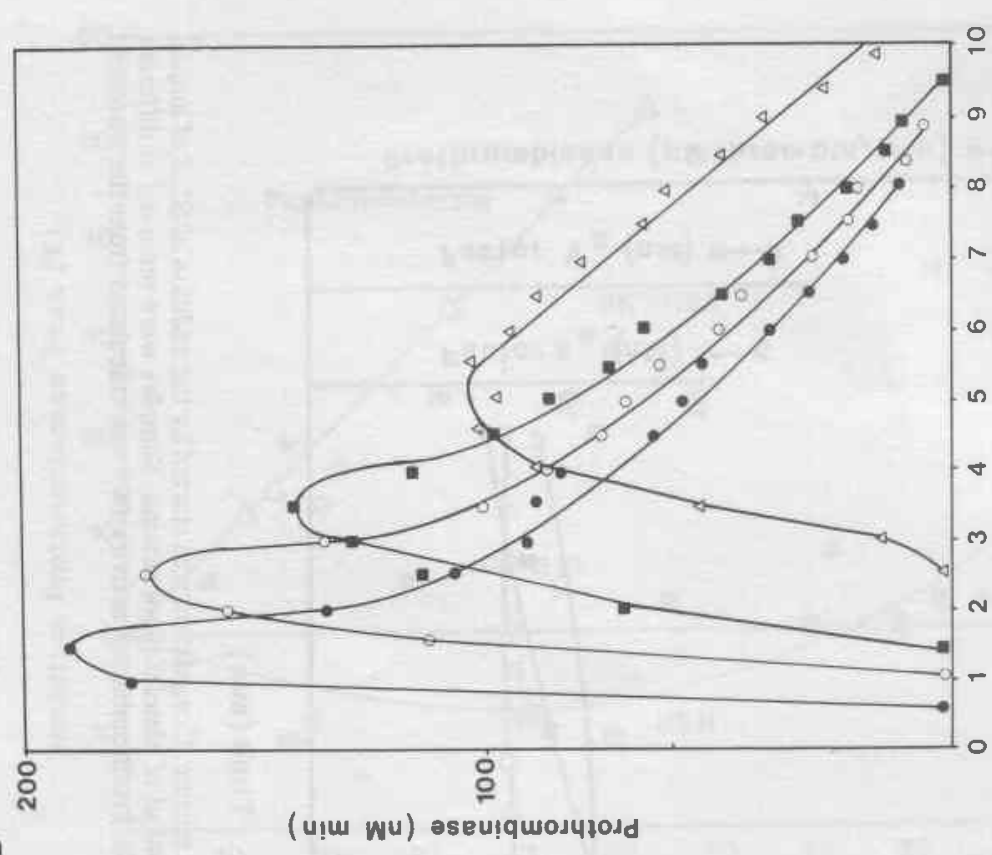

$\infty$

(u!w wu) aseu!quosulodd

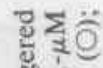

है

a $=05$

$\infty$ ⿷匚

ह $\stackrel{5}{\tilde{E}}$

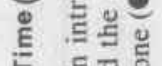

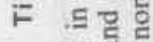

तथ

ㅎ․

प्ल क्ष

is 0.

때

है

을 행

ํํㅇํㅇㄷㅡ

ตㅇํㄹ

믈 $\frac{E}{9}$

要

ํํㅇ

影

政

용

등

ह

응음

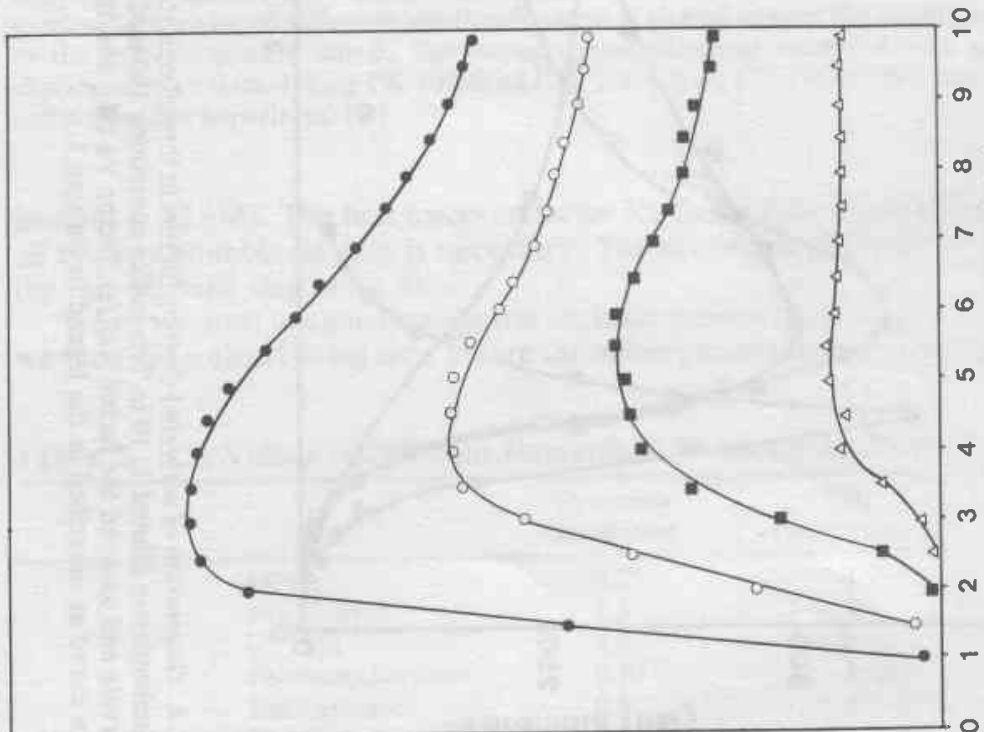

근

Sn

등

드응

고옹

․ㅡㄹ

동

ह

$\ddot{2}$.

을 중

흥

寻

를

ธ.

ठ

중

至

는 울

in $\frac{5}{8}$ 을

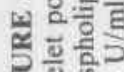

온 웅

흔믈

(wu) u!qw0 
of heparin these lag times are prolonged. Addition of preactivated factor VIII or addition of nanomolar amounts of thrombin to the plasma prior to starting the reaction abolishes this lag time. This is a direct indication that heparins also can inhibit prothrombinase formation by inhibiting the positive feedback activation of factor VIII by thrombin.

It is interesting to see that in intrinsic coagulation the amount of prothrombinase decreases when heparin is added. This cannot be attributed to factor Xa inactivation to a larger extent than in the extrinsic system because, as soon as the system is started with the factor $\mathrm{X}$ activating complex, the inhibition disappears. It must therefore be due to a decrease of the amount of tenase that is available. The formation of tenase depends on factor IXa and factor VIIIa generation. It has been demonstrated that the activation of factor IX is not inhibited by heparin. Thus, like the formation of the prothrombinase complex, it is reasonable to as-

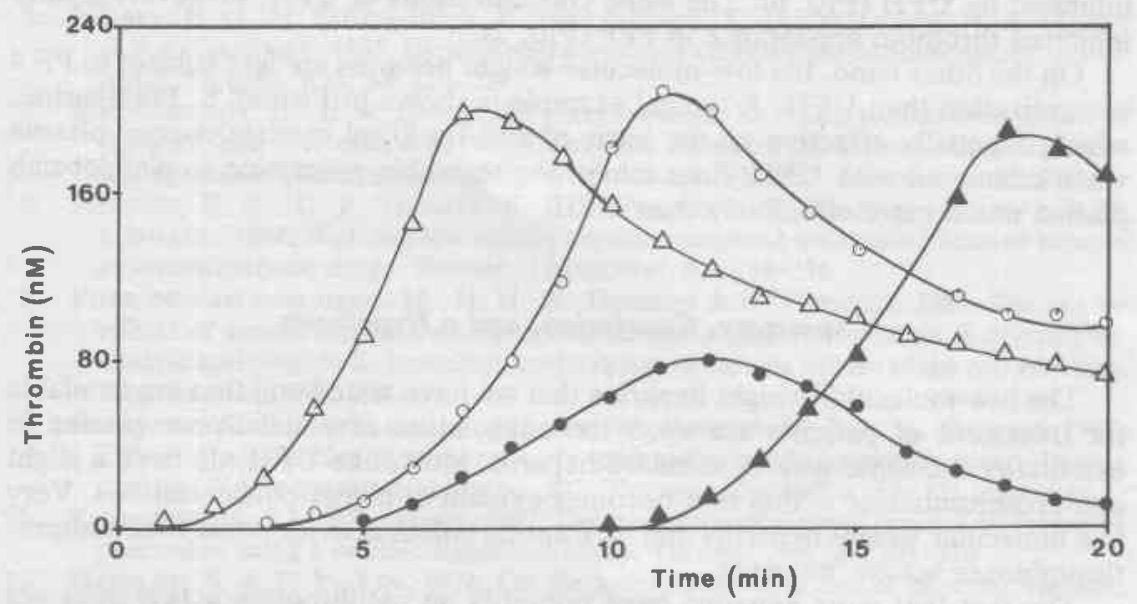

FIGURE 6. The influence of unfractionated heparin on thrombin generation in platelet-rich plasma. Experimental conditions as in FIGURE 2 but for the use of platelet-rich plasma $\left(3 \times 10^{8}\right.$ platelets $\left./ \mathrm{ml}\right)$ and human brain thromboplastin in a dilution of $1: 400$. The heparin concentrations were none $(\triangle) ; 0.1 \mathrm{U} / \mathrm{ml}(0)$; and $0.3 \mathrm{U} / \mathrm{ml}(\Delta)$. The low-molecular-weight heparin CY $216(\bullet)$ was present at 0.07 anti-IIa U/ml.

sume that formation of the factor-X-activating complex largely depends on the generation of the cofactor, factor VIIIa. Because thrombin is the main activator of factor VIII, low tenase concentrations might be explained by the heparin-mediated scavenging of thrombin. Alternatively, inactivation of noncomplexed factor IXa might also explain the reduced generation of tenase when heparin is present.

\section{The Action of Heparins in Platelet-Rich Plasma}

Thrombin generation in platelet-rich plasma (PRP) is an in vitro system that is one step nearer to physiological reality than thrombin generation in platelet-poor plasma (PPP). As we did not find essential differences between the mode of action of UFH and several LMWHs in platelet-poor plasma, it was a logical step to study platelet-rich plasma next.

Thrombin generation in PRP differs essentially from that in PPP in that it always shows a burst of thrombin formation after a lag time (FIG. 6). If no external 
trigger is added the lag phase lasts 10-12 minutes. Trace amounts of thromboplastin (final dilution in the system, 1:2400) shorten this lag by $3-5$ minutes. These concentrations of thromboplastin are without effect on PPP. We could show that the thrombin burst is caused by the production of procoagulant phospholipids by the platelets. Nanomolar amounts of thrombin generated during the lag time are instrumental in triggering the platelets.

All substances that inhibit thrombin formation or lower the ambient thrombin level by inactivation will prolong the lag time. ${ }^{39}$ This phenomenon therefore is produced by UFH, S-type LMWHs, P-type LMWHs, and hirudin alike. Once the platelets are activated, a curious difference of behavior appears among the various heparins. On the one hand unfractionated heparin appears almost completely neutralized by products from the activated platelets, i.e., platelet factor 4 (PF 4 ). As a consequence, the peak of the thrombin burst is only retarded but is not inhibited by UFH (FIG. 6). The same concentrations of UFH, however, greatly inhibited thrombin appearance in PPP (FIG. 2).

On the other hand, the low-molecular-weight heparins are less subject to PF 4 neutralization than UFH. A typical example is shown in FIGURE 6. Fraxiparine, which is equally effective on the basis of anti-IIa $\mathrm{U} / \mathrm{ml}$ in platelet-poor plasma when compared with UFH, does inhibit the thrombin generation in platelet-rich plasma much more effectively than UFH.

\section{Summary, Conclusion, and a Hypothesis}

The low-molecular-weight heparins that we have tested and that are available for treatment of patients act upon the coagulation of platelet-poor plasma in essentially the same way as standard heparin. Most, like UFH, do have a slight anti-prothrombinase action that becomes evident at higher concentrations. Very low molecular weight heparins that lack antithrombin activity retain their antiprothrombinase action, however.

The fact that most heparins have primarily an antithrombin action does not mean that they would not work on thrombin generation too. Both from our work and from that of others it appears that the product activation by thrombin is an essential feature of the natural clotting mechanism at least at three levels: platelet activation, factor V activation, and factor VIII activation. Both UFH and LMWH act primarily by inhibiting these feedback loops. We found only quantitative differences between the mode of action of commercially available LMWHs and UFH on this mechanism.

However, an essential difference between LMWH and UFH is their susceptibility to inactivation by PF 4 . Fully activated platelets at $3 \times 10^{8} \mathrm{ml}^{-1}$ are capable of neutralizing UFH concentrations that can almost completely inhibit thrombin formation in platelet-poor plasma. LMWH is neutralized to a much lesser extent. We hypothesize that this difference in PF 4 susceptibility explains much of the difference between LMWH and UFH. Thrombin generation in platelet-rich plasma is putatively the best predictor of in vivo antithrombotic action.

\section{ACKNOWLEDGMENTS}

We thank Paul Devilée for expert help with the experiments and Mrs. T. Camphuisen for preparing the manuscript. This work has been financially supported by the Dutch Thrombosis Foundation and La Fondation de France. 


\section{REFERENCES}

1. Glimelius, B., C. Busch \& M. Hook. 1978. Binding of heparin on the surface of cultured human endothelial cells. Thromb. Res. 12: 773-782.

2. Barzu, T., P. Molho, G. Tobelem, G. M. Petitou, M. \& J. P. Caen. 1985. Binding and endocytosis of heparin by human endothelial cells in culture. Biochim. Biophys. Acta 845: 196-203.

3. TURLEY, E. 1981. A role of glycosaminoglycans in cell adhesion and movement. In Chemistry and Biology of Heparin. Lundblad et al., Eds.: 121-131. Elsevier North Holland. New York.

4. Besterman, E. M. M. \& M. P. T. Gillet. 1973. Heparin effects on plasma lysolecithin formation and platelet aggregation. Artherosclerosis 17: 503-513.

5. Salzman, E. W., R. D. Rosenderg, M. H. Smith, J. N. Lindon \& L. Favreau. 1980. Effect of heparin and heparin fractions on platelet aggregation. J. Clin. Invest. 65: 64-72.

6. Vairel, E. G., H. Bouty-Boye, F. Toulemonde, C. Dotrempuich, N. A. Marsh \& P. J. GAFFNEY. 1983. Heparin and a low molecular weight fraction against thrombosis. Thromb. Res. 30: 219-224.

7. Bounameaux, H., H. R. Lijnen, H. Hellemans \& M. Verstraete. 1986. Effect of standard and low molecular weight heparin fractions on fibrinolysis and platelet aggregation in patients undergoing hysterectomy. Thromb. Haemostas. 55: 298.

8. Merton, R. E., D. P. Thomas, S. J. Havercroft, T. W. Barrowcliffe \& U. LINDAHL. 1984. High and low affinity heparin compared with unfractionated heparin as antithrombotic drugs. Thromb. Haemostas. 51: 254-256.

9. Boer de-van den Berg, M., H. H. W. Thijssen \& C. Vermeer. 1986. The in vivo effects of acenocoumarol, phenprocoumon and warfarin on vitamin $\mathrm{K}$ epoxide reductase and vitamin $\mathrm{K}$-dependent carboxylase in various tissues of the rat. Biochim. Biophys. Acta 884: 150-157.

10. Goldman, S., J. Copeland, T. Moritz, W. Henderson \& L. A. Harker. 1987. Effect of antiplatelet therapy on early graft patency after coronary artery bypass grafting: VA cooperative study no. 207. Thromb. Haemostas. 58: 221 (abstract).

11. KirchHof, B. \& L. Balleisen. 1982. Determination of platelet factor 3 by thrombin generation using a micro-coagulation assay. Thromb. Res. 27: 303-310.

12. WessleR, S. \& T. Y. YIN. 1974. On the antithrombotic action of heparin. Thromb. Diath. Haemorrh. 32: 71-82.

13. WESSLER, S. 1974. Small doses of heparins and a new concept of hypercoagulability. Thromb. Diath. Haemorrh. 33: 81-86.

14. Johnson, E. A., T. B. L. Kirkwood, Y. Stirring, J. L. Perez-Requejo, G. I. C. INGRAM, D. R. BANGHAM \& M. BrozoviA. 1975. Four heparin preparations: antiXa potentiating effect of heparin after subcutaneous injection. Thromb. Haemostas. 35: $586-591$.

15. Kakkar, V. V., B. Djazerri, J. Fok, M. Fletcher, M. F. Scully \& J. Westwick. 1982. Low molecular weight heparin and prevention of postoperative deep vein thrombosis. Br. Med. J. 284: 375-379.

16. Fussi, F., A. Girolami \& G. Cella. 1981. Low molecular heparins and their effects in vitro, in experimental models and in humans. In Chemistry and Biology of Heparin. R. L. Lundblad et al., Eds.: 535-546. Elsevier/North Holland. New York.

17. Thomas, D. P., R. E. Merton, W. E. LeWis \& T. W. Barrowcliffe. 1981. Studies in man and experimental animals of a low molecular weight heparin fraction. Thromb. Haemostas. 45: 214-218.

18. Holmer, E., C. Mattson \& S. Nilsson. 1982. Anticoagulant and antithrombotic effects of heparin and low molecular weight heparin fragments in rabbits. Thromb. Res. 25: 475-485.

19. Berqvist, D., U. Hedner, E. SJorn \& E. Holmer. 1983. Anticoagulant effects of two types of molecular weight heparin administered subcutaneously. Thromb. Res. 32: $381-391$.

20. Carter, C. J., J. G. Kelton, J. Hirsh, A. Cerskus, A. V. Santos \& M. Gent. 1982. 
The relationship between the hemorrhagic and antithrombotic properties of low molecular weight heparin in rabbits. Blood 59: 1239-1245.

21. Ockelford, P. A., C. J. Carter, L. Mitchell \& J. Hirsh. 1982. Discordance between the anti-Xa activity and the antithrombotic activity of an ultra low molecular weight heparin fraction. Thromb. Res. 28: 401-409.

22. Thomas, D. P., R. E. Merton, T. W. Barrowcliffe, L. Thunberg \& U. Lindahl. 1982. Effects of heparin oligosaccharides with high affinity for antithrombin III in experimental venous thrombosis. Thromb. Haemostas. 47: 244-248.

23. Cade, J. F., M. R. Buchanan, B. Boneu, P. Ockelford, C. J. Carter, A. L. CERSKUS \& J. A. HIRSH. 1984. A comparison of the antithrombotic and haemorrhagic effects of low molecular weight heparin fractions: The influence of the method of preparations. Thromb. Res. 35: 613-625.

24. Merton, R. E., D. P. Thomas, S. J. Havercroft, T. W. Barrowcliffe \& U. LINDAHL. 1984. High and low affinity heparin compared with unfractionated heparin as antithrombotic drugs. Thromb. Haemostas. 51: 254-256.

25. BuChanAN, M. R., B. BoneU, F. OFOSU \& J. HirSh. 1985. The relative importance of thrombin inhibition to the antithrombotic effects of heparin. Blood 65: 198-201.

26. Boneu, B., M. R. Buchanan, J. F. Cade, J. van Run, F. F. Fermendez, F. A. OFOSU \& J. HIRSH. 1985. Effects of heparin, its low molecular weight fractions and other glycosaminoglycans on thrombus growth in vivo. Thromb. Res. 40: 81-89.

27. Thomas, D. P., T. W. Barrowcliffe \& A. D. Curtis. 1986. Low molecular weight heparin. A better drug? Hemostasis 16: 87-92.

28. Hemker, H. C., G. M. Willems \& S. Beguin. 1986. A computer assisted method to obtain the prothrombin activation velocity in whole plasma independent of thrombin decay processes. Thromb. Haemostas. 56: 9-17.

29. Rosing, J., G. Tans, J. W. P. Govers-Riemslag, R. F. A. ZwaAl \& H. C. Hemker. 1980. The role of phospholipid and factor $\mathrm{Va}$ in the prothrombinase complex. J. Biol. Chem. 255: 274-283.

30. MarciniaK, E. 1973. Factor Xa inactivation by antithrombin III: Evidence for biological stabilization of factor Xa by Factor V phospholipid complex. Br. J. Haematol. 24: 391-400.

31. WALSH, P. N. \& R. BigGs. 1972. The role of platelets in intrinsic factor Xa formation. Br. J. Haematol. 22: 743-760.

32. Miletich, J. P., C. M. Jackson \& P. W. Majerus. 1978. Properties of the factor Xa binding site on human platelets. J. Biol. Chem. 253: 6908-6916.

33. Josso, F. \& S. BeguiN. 1981. Changes in the antithrombin III activity at the interface plasma-phospholipids. Thromb. Haemostas. 46: 285 (abstract).

34. ELLIS, V., M. F. ScULLY \& V. V. KAKKAR. 1984. Inhibition of prothrombinase complex by plasma proteinase inhibitors. Biochemistry 23: 5882-5887.

35. Barrowcliffe, T. W., S. J. Hayercroft \& G. Kemball-Cook. 1987. The effect of $\mathrm{Ca}^{2+}$, phospholipid and factor $\mathrm{V}$ on the anti-(factor $\mathrm{Xa}$ ) activity of heparin and its high-affinity oligosaccharides. Biochem. J. 243: 31-37.

36. Ofosu, F. A., A. L. Cerskus, J. Hirsh, L. M. Smith, G. J. Modi \& M. A. BlajchMAN. 1984. The inhibition of the anticoagulant activity of heparin by platelets, brain phospholipids and tissue factor. Br. J. Haematol. 57: 229-238.

37. WALKER, F. J. \& C. T. EsMON. 1979. The effects of phospholipid and factor Va on the inhibition of factor Xa by antithrombin III. Biochem. Biophys. Res. Commun. 90: 641-647.

38. Lindhout, T., D. Baruch, P. Schoen, J. Franssen \& H. C. Hemker. 1986. Thrombin generation and inactivation in the presence of antithrombin III and heparin. Biochemistry 25: 5962-5969.

39. Hemker, H. C. 1987. The mode of action of heparin in plasma. In Thrombosis and Haemostasis 1987. M. Verstraete et al., Eds. 17-36. Leuven University Press. 